\title{
On the enigma of Palaenigma wrangeli (Schmidt), a conulariid with a partly non-mineralized skeleton
}

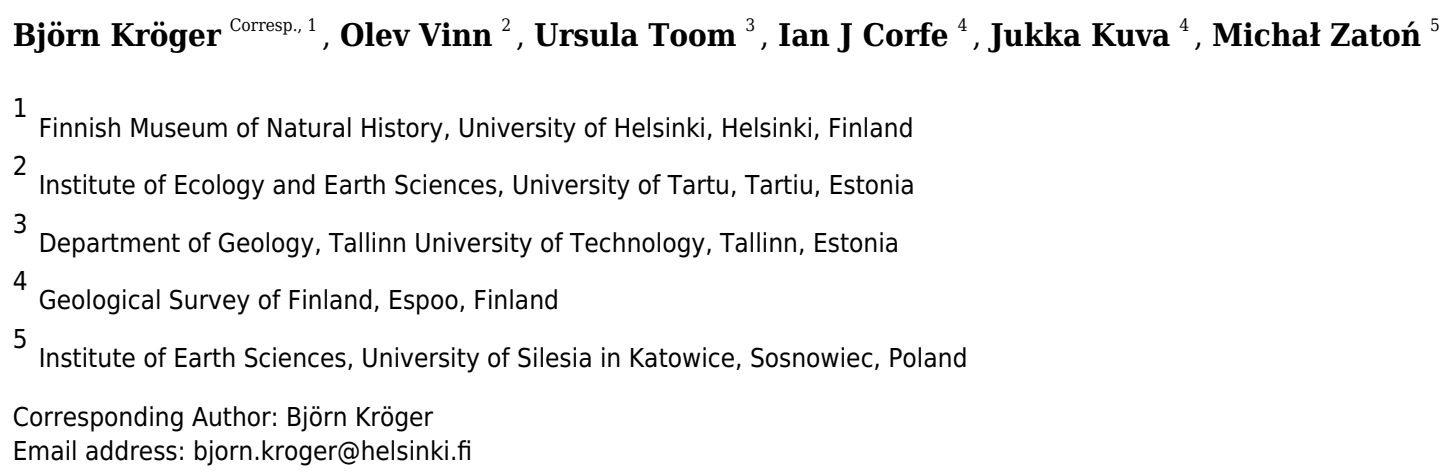

Palaenigma wrangeli (Schmidt) is a finger-sized fossil with a tetraradiate conical skeleton; it occurs as a rare component in fossiliferous Upper Ordovician strata of the eastern Baltic Basin and is known exclusively from north Estonia. The systematic affinities and palaeoecology of $P$. wrangeli remained questionable. Here, the available specimens of $P$. wrangeli have been reexamined using scanning electron microscopy and x-ray computed tomography (microCT). Additionally, the elemental composition of the skeletal elements has been checked using energy dispersive X-ray spectroscopy. The resulting 2D-, and 3Dscans reveal that $P$. wrangeli consists of an alternation of distinct calcium phosphate (apatite) lamellae and originally organic-rich inter-layers. The lamellae form four semicircular marginal pillars, which are connected by irregularly spaced transverse diaphragms. Marginally, the diaphragms and pillar lamellae are not connected to each other and thus do not form a closed periderm structure. A non-mineralized or poorly mineralized external periderm existed originally in $P$. wrangeli but is only rarely and fragmentary preserved. $P$. wrangeli often co-occurs with conulariids in fossil-rich limestone with mudstone - wackestone lithologies. Based on the new data, $P$. wrangeli can be best interpreted as a poorly mineralized conulariinid from an original soft bottom habitat. Here the new conulariinid family Palaenigmaidae fam. nov. is proposed as the monotypic taxon for $P$. wrangeli. 


\section{On the enigma of Palaenigma wrangeli (Schmidt), a 2 conulariid with a partly non-mineralized skeleton}

3

4 Björn Kröger ${ }^{1}$, Olev Vinn ${ }^{2}$, Ursula Toom ${ }^{3}$, Ian Corfe ${ }^{4}$, Jukka Kuva ${ }^{4}$, Michał Zatoń ${ }^{5}$

$5 \quad{ }^{1}$ Finnish Museum of Natural History, University of Helsinki, Helsinki, Finland

$6 \quad 2$ Institute of Ecology and Earth Sciences, University of Tartu, Estonia

$7 \quad 3$ Department of Geology, Tallinn University of Technology, Tallinn, Estonia

$8 \quad{ }^{4}$ Geological Survey of Finland GTK, Espoo, Finland

$9{ }^{5}$ Institute of Earth Sciences, University of Silesia in Katowice, Sosnowiec, Poland 10

11 Corresponding Author:

12 Björn Kröger ${ }^{1}$

13 PO Box 44, Helsinki, 00014, Finland

14 Email address: bjorn.kroger@helsinki.fi 
17 On the enigma of Palaenigma wrangeli (Schmidt), a conulariid with a partly non-mineralized skeleton

Björn Kröger ${ }^{1}$, Olev Vinn² ${ }^{2}$ Ursula Toom ${ }^{3}$, Ian Corfe ${ }^{4}$, Jukka Kuva ${ }^{4}$, Michał Zaton ${ }^{5}$

${ }^{1}$ Finnish Museum of Natural History, University of Helsinki, Helsinki, Finland

${ }^{2}$ Institute of Ecology and Earth Sciences, University of Tartu, Estonia

${ }^{3}$ Department of Geology, Tallinn University of Technology, Tallinn, Estonia

${ }^{4}$ Geological Survey of Finland GTK, Espoo, Finland

${ }^{5}$ Institute of Earth Sciences, University of Silesia in Katowice, Sosnowiec, Poland

Corresponding Author:

Björn Kröger ${ }^{1}$

PO Box 44, Helsinki, 00014, Finland

Email address: bjorn.kroger@helsinki.fi

\section{Abstract}

Palaenigma wrangeli (Schmidt) is a finger-sized fossil with a tetraradiate conical skeleton; it occurs as a rare component in fossiliferous Upper Ordovician strata of the eastern Baltic Basin and is known exclusively from north Estonia. The systematic affinities and palaeoecology of $P$. wrangeli remained questionable. Here, the available specimens of $P$. wrangeli have been reexamined using scanning electron microscopy and x-ray computed tomography (microCT). Additionally, the elemental composition of the skeletal elements has been checked using energy dispersive X-ray spectroscopy. The resulting 2D-, and 3D-scans reveal that $P$. wrangeli consists of an alternation of distinct calcium phosphate (apatite) lamellae and originally organic-rich inter-layers. The lamellae form four semicircular marginal pillars, which are connected by irregularly spaced transverse diaphragms. Marginally, the diaphragms and pillar lamellae are not connected to each other and thus do not form a closed periderm structure. A non-mineralized or poorly mineralized external periderm existed originally in $P$. wrangeli but is only rarely and fragmentary preserved. $P$. wrangeli often co-occurs with conulariids in fossil-rich limestone with mudstone - wackestone lithologies. Based on the new data, $P$. wrangeli can be best interpreted as a poorly mineralized conulariinid from an original soft bottom habitat. Here the new conulariinid family Palaenigmaidae fam. nov. is proposed as the monotypic taxon for $P$. wrangeli.

\section{Introduction}

The fossil Palaenigma wrangeli (Schmidt, 1874) is small, less than a small finger in diameter and no more than a couple of centimeters long. $P$. wrangeli has a peculiar tetraradiate symmetry with four, strange horn-like spines or pillars at each corner, and it consists of a shiny, dark-brown calcium phosphate, which cannot be overlooked on a freshly broken Ordovician limestone. 
57 The species name refers to Wilhelm F. Baron von Wrangell (1831-1894) (son of the famous

58

59

60

61

62

63

64

65

66

67

68

69

70

71

72

73

74

75

76

77

78

79

80

81

82

83

84

85

86

87

88

89

90

91

92

93

94

95

96 seaman Ferdinand von Wrangel), who found this fossil not far from his manor house when he was a young man only to urge twenty years later the Geologist Friedrich K. Schmidt (18321908) to solve its mystery. In his original description of the fossil, Schmidt (1874) reported the difficulties in finding more material. It took him two years and hours of focused searching to find another good specimen in a small quarry, where Wrangell guided him and his younger Swedish colleague Jonas. G. O. Linnarson (1841-1881). The quarry exposed the Lyckholmsche Schicht (corresponding to the Nabala and Vormsi Regional stages) and, according to Schmidt (1874), was very rich in conulariids. The dark phosphatic shell of conulariids and the skeleton of $P$. wrangeli stand out in the greenish-pale limestone, and if $P$. wrangeli were abundant, it would have been easy for the experienced and dedicated fossil hunters to find more material. $P$. wrangeli is generally a rare fossil, known exclusively from Estonia, and from Pleistocene erratic blocks from the Åland Islands, Finland and Uppland, Sweden (Holm, 1893). In the palaeontological collections of Estonia only seven specimens have been accumulated until now. The specimen found by Wrangell and the four or so, original specimens collected by Schmidt and Linnarson are unfortunately lost. Two specimens, probably collected by Linnarson, are in the collections of the Naturhistoriska Riksmuseet Stockholm (Sweden). All come from north Estonian light-coloured Upper Ordovician limestone, which is generally poor in skeletal intraclasts (Fig. 1).

Schmidt (1874) couldn't solve the mystery of Palaenigma, for which he created the separate genus Tetradium, a name that was already preoccupied by another enigmatic tetraradiate fossil organism (see Walcott, 1886; Steele-Petrovich, 2009). He speculated that it could be an operculum of a conulariid. Walcott (1886, p. 224) compared it with the Cambrian calcitic polyplacophoran Mattheva Walcott. Before, Lindström (1884, p. 41), in his opus magnum on Silurian gastropods of Gotland, excluded any relation with mollusks and curiously suggested that it might be a conulariid infected by a parasitic fungus. Later, Sinclair (1952) placed Palaenigma without comment into the Conulariinae, a subfamily of the Conulariida. The conulariid affinities of $P$. wrangeli also appeared unquestionable for Brood (1995), who briefly described the species and interpreted it as a basal part of Conularia Sowerby (Brood, 1995). The genus, however, was not included in the review and cladistic analysis of the Conulariinae carried out by Moraes Leme et al. (2008).

New finds from a small quarry in central Estonia exposing the Saunja Formation (Nabala Regional Stage) give reason to take the mysterious species under new scrutiny using modern analytical techniques. Here we describe the new material and review existing specimens available from the Estonian geoscience data platform (SARV, https://geocollections.info/), and the Naturhistorisk Riskmuseet Stockholm (NRM). SARV unites the large palaeontological collections from Estonia, and the specimens analyzed herein came from the Department of Geology at Tallinn University of Technology (GIT), the Natural History Museum, University of Tartu, and the Estonian Museum of Natural History. 


\section{Methods}

98 Four of the nine available specimens (see below) were investigated with a GE phoenix v|tome|x s

99 X-ray computed tomography (micro CT) device at the Geological Survey of Finland in Espoo,

100 Finland. The samples were imaged using an accelerating voltage of $80-100 \mathrm{kV}$ and a tube current

101 of 120-220 $\mu \mathrm{A}$, for a tube power of 12-22 W. Tube power was kept low enough to avoid spot

102 size - related blurring for the obtained resolutions of $12-20 \mu \mathrm{m} .0 .1 \mathrm{~mm}$ of $\mathrm{Cu}$ was used as a

103 beam filter in most scans. 2200-2500 angle steps were used and at each angle the detector waited

104 for a single exposure time and then took an average over three exposures, with the single

105 exposure time varying between 500-1000 ms. This resulted in total scan times of 73-167

106 minutes. The obtained projections were reconstructed using GE phoenix datos $\mid \mathrm{x}$ and investigated

107 using ThermoFisher PerGeos 2020.2.

108 The microstructural features of the specimens have been analyzed using a Thermo Scientific

109 Quanta 250 analytical scanning electron microscope (SEM) housed at the Institute of Earth

110 Sciences in Sosnowiec, Poland. The specimens have been inspected in uncoated states in low

111 vacuum conditions using back-scattered electrons (BSE) imaging. We used BSEs because they

112 deliver best quality images for skeletal fossils in a limestone matrix. BSE images were collected

113 using a Directional Backscatter Detector under the following operating conditions: $13 \mathrm{~mm}$

114 working distance, low vacuum mode (40 Pa chamber pressure, water vapour atmosphere), 15

$115 \mathrm{keV}$ beam accelerating voltage, and a $200 \mu \mathrm{m}$ aperture. Both transverse and sagittal sections of

116 the specimens have been investigated. The elemental composition of building structures and

117 layers have been checked using an energy dispersive X-ray spectroscopy (EDS). EDS was

118 conducted using a Thermo Scientific Noran System 7 and an UltraDry Premium EDS detector

119 using the same operating conditions as above. A Pathfinder EDS software was used for

120 acquisition of point counts and counts in a microarea. EDS analyses have been performed on

121 nine locations in different parts of the skeleton. At each location five to eleven points were

122 analyzed in order to evaluate the variability of the results (see Article S1). SEM and micro CT

123 images have been graphically improved by adjusting whole image Gamma and Contrast levels

124 using Affinity Photo Version 1.9.2 graphical software.

125 Herein, a few descriptive terms are used (Fig. 2), which are mainly borrowed from the literature

126 about conulariids: Periderm denotes the exoskeleton of conulariids. Carinae are broad, internal

127 thickenings of the periderm that can be situated on the sides of the periderm or as keel-like,

128 continuous thickenings at the corners of the periderm. In many conulariids there are multiple

129 kinds of internal thickenings, collectively assigned by Van Iten (1992) to 11 types of internal

130 midline (interradial) structures and two types of internal corner (perradial) structures. Septa are

131 longitudinal walls, keels, and deep ridges in the interior of the periderm positioned at the

132 midline. Diaphragms are horizontal truncations of the periderm well above the apex. At the

133 position of a diaphragm the periderm tapers to an imperforate, usually adapically convex

134 transverse wall, often also called the "apical wall" (e.g., Babcock \& Feldman, 1987) or "schott"

135 (e.g., Kiderlen, 1937; Van Iten, 1991). 
136 The compilation of conulariid specimens is based on a search in the SARV database (accessed

137 08.04.2021) under the following link:

$138 \mathrm{http} / / /$ geocollections.info/specimen?specimen_number_1=1\&specimen_number=\&collection_id

$139 \_1=1 \&$ collection_id $=\&$ classification_ $1=2 \&$ classification $=\&$ taxon_ $1=2 \&$ taxon=conulari\&name 140 geology_1=1\&name_geology $=\&$ country_ $1=1 \&$ country $=\&$ locality_ $1=1 \&$ locality $=\&$ stratigraphy

141 _1 $=11 \&$ id_ $1=5 \& \mathrm{id}=\&$ depth_since_ $1=12 \&$ depth_since $=\& d e p t h \_$to $\_1=13 \&$ depth_to $=\&$ agent_1 $=$ $1421 \&$ agent $=\&$ reference_ $1=1 \&$ reference $=\&$ original_type_1 $=1 \&$ original_type $=\&$ part_ $1=1 \&$ part $=\&$

143 date_taken_since_1 $=12 \&$ date_taken_since $=\&$ date_taken_to_1 $1=13 \&$ date_taken_to $=\& \mathrm{dbs} \% 5 \mathrm{~B} \%$ $1445 \mathrm{D}=1 \& \mathrm{dbs} \% 5 \mathrm{~B} \% 5 \mathrm{D}=2 \& \mathrm{dbs} \% 5 \mathrm{~B} \% 5 \mathrm{D}=3 \&$ currentTable $=$ specimen $\&$ max Size $=5 \&$ page $=1 \&$ pagi

145 nateBy $=25 \&$ sort=locality_locality_en\&sortdir=DESC

146 The electronic version of this article in Portable Document Format (PDF) will represent a

147 published work according to the International Commission on Zoological Nomenclature (ICZN),

148 and hence the new names contained in the electronic version are effectively published under that

149 Code from the electronic edition alone. This published work and the nomenclatural acts it

150 contains have been registered in ZooBank, the online registration system for the ICZN. The

151 ZooBank LSIDs (Life Science Identifiers) can be resolved and the associated information viewed

152 through any standard web browser by appending the LSID to the prefix http://zoobank.org/. The

153 LSID for this publication is urn:lsid:zoobank.org:pub:E466B5EF-0637-4F6F-917C-

154 4D0D7EF41B9F. The online version of this work is archived and available from the following

155 digital repositories: PeerJ, PubMed Central and CLOCKSS.

156 The Supplemental Information (Article S1, Data S1, Video S1-S3) for this article is available at

157 www.zenodo.org/10.5281/zenodo.5205763. Reconstructed microXCT data is deposited with the

158 MorphoSource repository (www.morphosource.org) in the Palaenigma project at the following

159 DOI addresses:

160 Specimen GIT 812-34: https://doi.org/10.17602/M2/M368045

161 Specimen NRM-Mo 153045: https://doi.org/10.17602/M2/M368741

162 Specimen GIT 655-3: https://doi.org/10.17602/M2/M368879

163 Specimen GIT 812-35 (includes conulariid specimen GIT 812-35-1):

164 https://doi.org/10.17602/M2/M369289

165 All microXCT images and videos associated with this study are available from the CSC Fairdata-

166 PAS service, at https://www.doi.org/10.23729/3eaf1aeb-5e0c-4704-9e18-a925688f810b.

167

\section{Geological setting}

169 All specimens of $P$. wrangeli described herein have been collected from localities in north

170 Estonia, exposing Upper Ordovician strata either in natural outcrops or in drill cores (Fig. 1A).

171 The sediments of north Estonia are tectonically nearly undisturbed and palaeogeographically

172 represent the eastern part of the Baltic Palaeobasin of the Baltica Palaeocontinent (Männil, 1966;

173 Jaanusson, 1979; Nestor \& Einasto, 1997). During the Late Ordovician the sedimentary

174 deposition in north Estonia was dominated by limestone and marlstone in temperate to tropical

175 marine settings (Cocks \& Torsvik, 2005; Dronov and Rozhnov, 2007). The area comprises the

176 North Estonian Facies Belt or North Estonian Shelf which, toward the south, grades into the

177 Livonian Basin (Jaanusson 1979; Nestor \& Einasto, 1997, Fig. 1B). The sediments of the North

Peer] reviewing PDF | (2021:04:60056:2:0:NEW 27 Sep 2021) 
178 Estonian Shelf are predominantly neritic to shallow marine and individual sedimentary packages

179 are locally divided by long depositional hiati and partially by erosional horizons (Raukas \&

180 Teedumäe, 1997). A well-established regional chronostratigraphic, lithostratigraphic and

181 biostratigraphic scheme allows for high resolution correlation of the north Estonian Upper

182 Ordovician sediments (e.g., Raukas \& Teedumäe, 1997; Nõlvak, Hints \& Männik, 2006; Meidla,

183 Ainsaar \& Hints, 2014, Fig. 1C).

184

\section{Material}

186 The type locality of $P$. wrangeli was given by Schmidt (1874) as a quarry belonging to Küti

187 (German "Kurküll"), a manor near Viru-Jaagupi in northeastern Estonia. According to (Schmidt,

188 1858) the quarry was located south-west of manor house near Aruküla village (German

189 "Arroküll"). The quarry was abandoned a long time ago and today is untraceable, its former

190 location is indicated by the place name Lubjaahju (Estonian for Lime Kiln) $\left(59^{\circ} 11^{\prime} 43.2^{\prime \prime} \mathrm{N}\right.$

$19126^{\circ} 30^{\prime} 00.4^{\prime \prime E}$ ). It exposed a pale-grey limestone of the Nabala and Vormsi stages (Rõõmusoks,

192 1966). The quarry was repeatedly visited by Schmidt $(1858,1874)$ because of its fossil richness.

193 The abundance of conulariids was specifically mentioned and listed by Schmidt $(1858,1874)$

194 and is also documented in the SARV database by an impressive number of more than 60

195 conularid specimens collected from the old Küti quarry. According to Rõõmusoks (1966) the

196 richness is mainly limited to the Vormsi Stage; he listed brachiopods (mainly Sampo hiiuensis

197 (Öpik), Ilmarinia sinuata (Pahlen), Kiaeromena (Bekkeromena) vormsina Rõõmusoks), hyoliths,

198 gastropods, heliolitid tabulates, rugose corals, receptaculitids, and trilobites (mainly

199 Toxochasmops vormsiensis Rõõmusoks). Two specimens of $P$. wrangeli from Küti are available

200 from the collections of the NRM (NRM-Mo 153045, 153046) (Figs 3C-D). The lithological

201 information available from matrix of these specimens is consistent with an origin from the

202 Kõrgessaare Formation, Vormsi Stage. The Kõrgessaare Formation consists of an argillaceous,

203 heavily bioturbated, greenish to yellowish pale-coloured mud-wackestone (Oraspõld \& Kala,

204 1980).

205 Two specimens (GIT 812-34, Fig. 3F-G, and GIT 812-35) were collected at the Sutlema quarry,

206 west of Sutlema village, Rapla County, central Estonia (59 $\left.10^{\prime} 26.28^{\prime \prime} \mathrm{N}, 24^{\circ} 37^{\prime} 2.62^{\prime \prime} \mathrm{E}\right)$. The

207 active quarry exposes the Saunja Formation (Nabala Stage) and the Kõrgessaare Formation

208 (Vormsi Stage). Both specimens came from the Saunja Formation. At Sutlema the Saunja

209 Formation contains a rich fauna and flora, dominated by green algae (Vermiporella Stolley,

210 Coelosphaeridium Roemer, and an unidentified delicate dendroid form), gastropods (large

211 Murchisonia-like forms, Hormotoma insignis Eichwald) and sponges. Additionally, bivalves,

212 brachiopods [Kiaeromena (Bekkeromena) ilmari Rõõmusoks], cephalopods, conulariids,

213 receptaculitids, rugose corals, trilobites, stromatoporoids, and dendritic graptolites (Dictyonema

214 sp.) occur. The rich fauna of the quarry needs a detailed taxonomic examination. The Saunja

215 Formation is more than $10 \mathrm{~m}$ thick at Sutlema and consists of a bioturbated, massively bedded,

216 light-colored mud-wackestone, typical for the Baltic Limestone Facies (Kröger et al., 2019).

217 Three additional specimens come from drillcores, with little information on co-occurring fauna: 
218 Specimen GIT 655-1 was collected from Kükita 24 drillcore (58 $\left.48^{\prime} 18.9^{\prime \prime} \mathrm{N} 26^{\circ} 56^{\prime} 32.5^{\prime \prime E}\right)$, c. 4

$219 \mathrm{~km}$ south of Mustvee, Mustvee Parish, west of Lake Peipsi, north-east Estonia, from depth 84.35

$220 \mathrm{~m}$, Tudulinna Formation, Vormsi Stage. The faunal content of the Vormsi interval of the

221 drillcore is remarkably rich and comprises a delicate dendroid bryozoa (Stictopora sp.), a

222 trilobite (Isotelus sp.), a hyolithid (Dorsolinevitus vomer Holm), a conulariid, and the putative

223 cnidarian Sphenothallus (Vinn \& Kirsimäe, 2014).

224 Specimen GIT 655-2 (Fig. 3E) was collected from Ellavere drillcore $\left(59^{\circ} 0^{\prime} 52.42 " \mathrm{~N}, 26^{\circ}\right.$

225 1'24.89"E), c. 8 km south-east-east from Järva-Jaani, Järva County, north-east Estonia, depth

$22692.70 \mathrm{~m}$. At the same horizon occurs a bellerophontid [Megalomphala crassa (Koken)], and a

227 brachiopod [Cyrtonotella kuckersiana cf. kuckersiana (Wysogorski)]. The specimen GIT 655-2

228 occurs in a greenish - grey, bioturbated argillaceous skeletal mud- wackestone of uncertain

229 stratigraphy, probably from Vormsi Stage.

230 Specimen GIT 655-3 was collected from Mustvee 2322 drillcore, $3 \mathrm{~km}$ west of Mustvee, a

231 village at the shore of the Lake Peipsi, north-east Estonia (58 50'5.41"N, 26 $53^{\circ} 19.79 " \mathrm{E}$ ), depth

$23269.15 \mathrm{~m}$, from an interval within the Pirgu Stage. It occurs in a greenish gray, bioturbated,

233 nodular argillaceous limestone of the Adila Formation.

234 Two specimens have been detected in the collections after completion of the micro CT and SEM

235 analyses for this review: Specimen GIT 575-43, from Mäemetsa Quarry, Harju County, Saunja

236 Formation, Nabala Stage (Figs 3A-B); and specimen GIT 655-4, from Pala 70 drillcore at

237143.90 m, Jõgeva County, Pirgu Stage.

238

239 Results

240 Morphology

241 The available specimens show some generalities in skeletal morphology. All specimens consist

242 of four equidistant marginal pillars with diameters of up to $3 \mathrm{~mm}$. The distance of the pillars

243 increases at a constant angle of c. $13^{\circ}$ toward a maximum preserved periderm diameter of c. 10

$24411 \mathrm{~mm}$ (Specimen GIT 812-34, Fig. 4). The four pillars are apically interconnected by irregularly

245 spaced transverse diaphragms, which are slightly irregularly curved toward the apex of the pillars

246 (Fig. 5). The pillars have a roughly semicircular cross section, which results from a relatively

247 loose and irregular cone-in-cone succession of superimposed tubular shell layers exclusively on

248 the inner side of the pillars (Fig. 5B-C, Fig. 6C, Videos S1-S2). The centers of the outer surface

249 of the pillars are not covered with a continuous shell layer but expose, as a quasi-cross section,

250 the complete succession of layers (Figs 5C-D). This results in a longitudinally carinate

251 appearance of the outer surface of the pillars.

252 The diaphragms are continuations of individual pillar layers or sheets, with the oldest and

253 apicalmost diaphragms representing the most distal, oldest pillar layers. The thickness of the

254 diaphragms is similar to that of the laminae of the pillars, c. 10-80 $\mu \mathrm{m}$. The shape of the

255 diaphragms can be deeply conically curved, such as in specimen Mo 153045 (Fig. 6), or shallow

256 bowl-shaped, such as in specimen GIT 655-3 (Fig. 7). 
257 The transverse shape of the septa is nearly quadratically and the pillars are positioned at or near

258 the four centers of the square margins, which would correspond to the midlines of the four

259 periderm-faces of a conulariid (Fig. 6C, D).

260 The height of the individual cones of the pillars is more than what is preserved in the available

261 specimens and thus exceeds $15 \mathrm{~mm}$. Hence, the skeletal material accreted in form of clearly

262 distinguishable, separate layers or sheets from the outer margins of the periderm toward its

263 center.

264 The apical end of the skeleton is open, and the pillars are not in contact with each other at their

265 apical tip. The first septum occurs at a face width of $6 \mathrm{~mm}$ in specimen GIT 812-34 and at a face

266 width of $8.5 \mathrm{~mm}$ in specimen Mo 153045.

267 In specimen GIT 655-3 the pillars are additionally thickened by massive flange-like skeletal

268 sheets, which merge toward the periderm center with thick diaphragms (Fig. 7). A similarly

269 thickened pillar section is preserved in specimen Mo 153045 (Figs 6A, B).

270 Notably in specimen Mo 153045, GIT 655-1, and GIT 655-3 skeletal fragments of thin cone

271 shaped skeletal sheets or walls with a fragile lattice-like texture are preserved in proximity of $P$.

272 wrangeli (Figs 8A-C). These sheets in specimen Mo 153045 are longitudinally bent or folded

273 forming sharp angles and flat faces. The shape of the sheets and the lattice-like structure is

274 similar to co-occurring conulariid periderms (Fig. 8C, Video S3). In specimen GIT 655-1,

275 fragments of a finely transversely annulated or ribbed phosphatic sheet are preserved near the

276 outer margin of a pillar (Figs 9A, D, Article S1). Additionally, in specimen GIT 575-43 (Figs

277 3A-B) a part of the periderm is preserved in which the four pillars decrease in thickness along $\mathrm{c}$.

$27815 \mathrm{~mm}$ and eventually taper off toward the aperture. The four pillars are positioned at the inner

279 surface of the impressions of a tubular poorly skeletonized wall with a quadratic cross-section.

280 This outer wall has a maximum face width of $>10 \mathrm{~mm}$. Faint traces of a face-midline are

281 preserved along the adoral part of the specimen. In well preserved portions the wall surface

282 shows a fine lattice like pattern.

283

284

285

286

287

288

289

290

291

292

293

294

295

296

\section{Microstructure}

ESEM observations of $P$. wrangeli reveal that different parts of the skeleton have a similar microstructure, consisting of several distinct thin lamellae (Fig. 9). Results from EDS from more than 80 points measured at lamellae surfaces and from transverse cracks of pillars at specimens GIT 655-1 and GIT 655-2 consistently indicate fluoroapatite as the skeletal material (see Article S1) and support previous assumptions (e.g., Schmidt, 1874, p. 44). This is similar to conulariids and Sphenothallus (e.g., Holm, 1893; Brood, 1995; Vinn \& Kirsimäe, 2015; Ford, Van Iten \& Clark, 2016). The thicknesses of individual lamellae vary, ranging from c. 10 to $80 \mu \mathrm{m}$. As in Sphenothallus, the boundaries between lamellae can be more or less sharp. In several places, within a single lamella much thinner (c. 0.5 to $0.8 \mu \mathrm{m}$ thick) laminae occur which may mark here a primary lamination. The microstructure of individual lamellae seems to be homogeneous, composed of tiny phosphate crystals. Sometimes, however, within particular solid lamellae, empty spaces may occur, which are exclusively visible in ESEM observations (Figs 9G-I). Such 
297 spaces have a limited extent and are filled by microcrystalline calcium phosphate. In some areas

298 the interspaces between successive laminae contain phosphatic aggregations of thin (c. 1.5-1.8

$299 \mu \mathrm{m}$ in diameter), branching and diverging filaments. Some of the laminae also possess pores and

300 empty chimney-like structures, with an inner diameter up to $4 \mu \mathrm{m}$ (Fig. 9H).

301 In the distalmost part of the skeleton of the specimen GIT 655-2 an extremely thin (up to $1 \mu \mathrm{m}$ )

302 outermost layer occurs, on which tiny (c. $16 \mu \mathrm{m}$ in diameter), circular bumps (papillae) occur

303 (Figs 9B, E, F). These structures may be isolated or associated in small groups. In some places,

304 additionally smaller wrinkle-like structures (shrinkage features?) also occur (Fig. 9F). The

305 wrinkled and papillate layer is covered from the inside by homogeneous skeletal layers devoid of

306 such structures.

307

308 Discussion

309 Interpretation of the shell microstructure

310 The distinct lamellae of the skeleton of $P$. wrangeli partly contain fine irregular vertical

311 perforations, chimney-like structures (Fig. 9H), and additionally in some places the lamellae-

312 interspaces are filled with a layer of fine filamentous phosphatic aggregations (Fig. 9H-I). The

313 chimney-like structures may be interpreted as original pore-like anatomical structures, because

314 these structures appear to be limited to the papillate layer and there the shell lamina are often

315 deflected toward the perforations. If so, it can be hypothesized that the papillate thin layer in

316 specimen GIT 655-2 represents the remnants of the inner side of an external covering periderm.

317 However, the filled perforations in other areas of the shell are less regular, and the presence of

318 filamentous micro-apatitic aggregations (Fig. 9I, Article S1) in some of the lamellae-interlayers

319 can be best interpreted as a product of microbial and fungal degradation of originally organic-

320 rich laminae (compare e.g., Størmer, 1931; Podhalańska \& Nõlvak, 2009). Such an interpretation

321 is supported by findings of Broda \& Zaton (2017, fig. 3A, C), which showed that filamentous

322 fungi or bacteria bored through a cuticle of a Devonian thylacocephalan arthropod and spread

323 horizontally between the laminae, indicating originally present organic matter within the

324 thylacocephalan exoskeleton. Hence, the filamentous structures found in Palaenigma may

325 indicate the presence of originally organic layers in between the phosphatic lamellae, which were

326 post-mortem infested by boring microbial-fungal consortia. Similar, alternating phosphatic-

327 organic layers also occur in skeletons of conulariids (Ford et al. 2016) and Sphenothallus (Vinn

328 \& Kirsimäe, 2015; Vinn \& Mironenko, 2020). Sphenothallus, which is interpreted as a cnidarian

329 (e.g., Van Iten et al. 2019), probably with close affinities to conulariids (Vinn \& Mironenko,

330 2020), has a lamellate tubular phosphatic skeleton like conulariids, but differs from the latter

331 mainly in lacking a tetraradiate skeletal symmetry and in having a distinct clonal budding pattern

332 (Van Iten et al. 2019).

333

334 Systematic affinities

335 The surrounding enigma of $P$. wrangeli has two aspects: the first refers to the anatomical

336 interpretation of the skeletal structures, and the second one, which relates to the first one, refers 
337 to its systematic affinity. Both mysteries can be partly solved with the new evidence from the

338 examinations performed herein.

339 The preserved skeletal parts of $P$. wrangeli are invariably composed of calcium phosphate (see

340 Article S1, presumably of apatite, such as in conulariids and Sphenothallus, Vinn \& Kirsimäe,

341 2015). The 3D-reconstruction and ESEM examination of several well-preserved specimens

342 reveals a consistent tetraradiate symmetry of the $P$. wrangeli skeleton with four semicircular

343 marginal pillars, which are connected by irregularly spaced transverse diaphragms and which

344 form a cone-like skeleton with an angle of c. $13^{\circ}$. The pillars and diaphragms are formed by a

345 cone-in-cone structure of distinct sheets, which are accreted from the outer margin of the entire

346 structure toward the center and from the apex toward the opening of the cone. Marginally, the

347 diaphragms are not connected to each other except at the position of the pillars and thus do not

348 form a closed structure. Similarly, the pillar-layers are open toward its margin and end abruptly

349 at the outer surface of the pillars, resulting in a semicircular pillar cross-section and in a peculiar

350 longitudinally lirate relief of the external pillar surface. The abrupt ending of the skeletal sheets

351 at the margins of the diaphragms and at the external surfaces of the pillars suggests the presence

352 of an organic or poorly mineralized outer cover or periderm, which is not fossilized in most

353 specimens, and which served as an attachment structure and matrix for the formation of

354 diaphragms and the external pillar surface. Traces and fragments of such a periderm are

355 preserved in several specimens and can be reconstructed as an outer wall with quadratic cross-

356 section and a fine lattice-like ornament.

357 In summary, the skeleton of $P$. wrangeli exhibits characters, known in its combination only in

358 the Conulariina: 1) skeleton composed of calcium phosphate, 2) tetraradial, slender cone with

359 thickened longitudinal septa at midline position and transverse diaphragms, 3) skeletal sheets

360 forming irregularly and loosely spaced cone-in-cone structures. Poorly preserved, lightly

361 mineralized phosphatic, transversely ornamented walls could be interpreted as remains of a

362 periderm. Therefore, $P$. wrangeli can be best interpreted as a conulariid with a poorly

363 mineralized marginal periderm, phosphatic apical pillars and diaphragms. The pillars with their

364 flat external surfaces can be best interpreted as homologue to the mineralized longitudinal septa

365 at midline position in the Conulariina (see e.g., Ford, Van Iten \& Clark, 2016; Moraes Leme et

366 al., 2008).

367 Taking the general similarities and distinct constructional differences into account, it is evident

368 that $P$. wrangeli should be placed to a separate conulariid family. Here we suggest the new

369 family Palaenigmaidae fam. nov. urn:1sid:zoobank.org:act:D1F2ED63-5711-4882-A7E2-

370 CA521D6AE09F for Conulariina with steeply pyramidal skeletons with a thin chitinophosphatic

371 periderm that consist of four equidistant marginal pillars, without or with poorly biomineralized

372 outer shell; the apical end of the skeleton is open, and the pillars are not in contact with each

373 other at their apical tip. P. wrangeli is the only species of the Palaenigmaidae fam. nov.

374

375

Palaeoecology 
376 In his original description, Friedrich Schmidt noticed the extraordinary abundance of co-

377 occurring conulariids with specimens of $P$. wrangeli in the type locality of Küti, north-east

378 Estonia (Schmidt, 1874). A co-occurrence of $P$. wrangeli with conulariids was described from

379 Baltic Limestone boulders from Sweden (Holm, 1893). And conulariids are also relatively

380 common in the Sutlema quarry, where two specimens of $P$. wrangeli have been found, as well

381 (see above).

382 The compilation of conulariids in the SARV database allows for an investigation of the question

383 whether this co-occurrence of $P$. wrangeli with conulariids represents a general pattern.

384 Conulariids inhabited the eastern part of Baltica basin from the Darriwilian (Kunda Stage)

385 onwards throughout the Silurian. They reached their Ordovician abundance climax within the

386 Haljala Stage with 127 specimens in the collections from 18 different localities. A second

387 abundance peak was reached during the Vormsi Stage, from which 51 specimens from seven

388 different localities are known (Fig. 10, Data S1). Most of the known specimens of $P$. wrangeli,

389 including the type specimens, are also from the Vormsi Stage. This seems to support the idea that

390 conulariids and $P$. wrangeli shared general habitat preferences and /or preservation pattern.

391 Based on the specimens available for this study, $P$. wrangeli and the Late Ordovician conulariids

392 of the eastern Baltica basin occur preferentially in depositional settings within an originally

393 extraordinarily faunal-rich, calcareous soft substrate habitat (see references in section "Material",

394 and Toom, Vinn \& Hints, 2019; Kröger et al. 2019 for evidence of widespread calcareous soft

395 substrate at $P$. wrangeli occurrences).

396 Neither the extreme apices of $P$. wrangeli, nor that of co-occurring conulariids are known.

397 Firmly skeletonized apical holdfast structures occur in Late Ordovician conulariids and

398 conulariid-like fossils (Kozlowski, 1968; Brood, 1995; Robson \& Young, 2013, see also

399 Sendino, Broda \& Zatoń, 2017). These holdfasts are discoidal or rootlet-like, indicating

400 differentiated conulariid attachment on hard substrate (discoids) and soft substrate (rootlets).

401 Rootlet-like skeletal appendages are often interpreted as functioning for stabilization and

402 attachment within soft substrate (e.g., Kozlowski, 1968; Seilacher \& MacClintock, 2005). The

403 thickened and reinforced apical septa of $P$. wrangeli are unknown from other conulariids. As a

404 speculation, these structures could have served as anchors, which weighted the apices down in a

405 muddy substrate. Elongated, stick-like conch forms, similar to that of conulariid periderms occur

406 in mud-sticking bivalves, such as Pinna Linnaeus, which shares even more similarities with

407 conulariids in having a subquadratic conch cross section (see e.g., Seilacher, 1984). However,

408 more complete apical material of $P$. wrangeli is needed to substantiate, this hypothesis.

409

410 Conclusions

411 Paleaenigma wrangeli (Schmidt, 1874) is a rare fossil known from few specimens collected

412 from Upper Ordovician limestone outcrops across northern and central Estonia and from erratic

413 boulders in Finland and east central Sweden. The systematic affinities of the monotypic

414 Paleaenigma were disputed. A thorough analysis of well-preserved specimens with X-ray

415 computed tomography, scanning electron microscopy, and energy dispersive X-ray spectroscopy 
416 reveal that the skeleton of $P$. wrangeli is composed of distinct calcium phosphate (apatite)

417 lamellae. The lamellae are partly porous and ornamented with distinct papillae and contain 418 poorly mineralized interlayers. The skeleton consists of four pillars, which are connected by 419 irregularly spaced diaphragms and which are marginally open. The diaphragms are quadratic in

420

421

422

423

424

425

426

427

428

429

430

431

432

433

434

435

436

437

438

439

440

441

442

443

444

445

446

447

448

449

450

451

452

453

454

455

456

457 transverse view and the pillars are situated at the four sides of the diaphragm squares. In few specimens remains of thin, poorly preserved transversally ornamented apatitic tube-forming walls are preserved near the distal margins of the pillars. Therefore, $P$. wrangeli can be best interpreted as a conulariid with a poorly mineralized marginal periderm, phosphatic apical pillars at midline position, and diaphragms. The new monospecific family Palaenigmaidae fam. nov. is proposed for $P$. wrangeli. Conulariids often co-occur with $P$. wrangeli. A comparison of other conulariid occurrences in Estonia with $P$. wrangeli occurrences indicates that these fossils are most abundant in depositional settings within an originally extraordinarily faunal-rich, calcareous soft substrate habitat. Based on its general morphology $P$. wrangeli can be interpreted as a poorly mineralized conulariid with a mud-sticking original life habit.

\section{Acknowledgements}

We are grateful to Mare Isakar (Tartu, Estonia) and Christian Skovsted (Stockholm, Sweden) for help with finding material and early suggestions on how to proceed with the review of the material. Anna Madison (Moscow, Russia) and Aleksey Sokolov, Vadim Glinskiy, and Galina Gataulina (St. Petersburg, Russia) helped to gather information on the (missing) type material. Gennady Baranov (Tallinn, Estonia) and Duncan Matthews (Helsinki, Finland) where supportive and important companions during field trips.

\section{References}

Babcock LE, Feldmann RM, Wilson MT. 1987. Teratology and pathology of some Paleozoic conulariids. Lethaia 20(2):93-105.

Broda K, Zatoń M. 2017. A set of possible sensory system preserved in cuticle of Late Devonian thylacocephalan arthropods from Poland. Historical Biology 29:1045-1055.

Brood K. 1995. Morphology, structure, and systematics of the conulariids. GFF 117:127-137.

Cocks RLM, Torsvik TH. 2005. Baltica from the late Precambrian to mid-Palaeozoic times: The gain and loss of a terrane's identity. Earth-Science Reviews 72:39-66.

Dronov A, Rozhnov SV. 2007. Climatic changes in the Baltoscandian basin during the Ordovician: sedimentological and palaeontological aspects. Acta Palaeontologica Sinica 46:108-113.

Ford RC., Van Iten H, Clark GR. 2016. Microstructure and composition of the periderm of conulariids. Journal of Paleontology 90:389-399.

Holm G. 1893. Sveriges kambrisk-siluriska Hyolithida och Conularida. Geologiska Undersökning, Afhandlingar och uppsatser C 112:1-172.

Jaanusson V. 1979. Karbonatyne postrojki v ordovike Shvetsii. Izvestyia Akademii Nauk Kazakhsko SSR 4:92-99.

Kiderlen H. 1937. Die Conularien. Über Bau und Leben der ersten Scyphozoa. Neues Jahrbuch für Mineralogie, Beilage Band 77:113-169. 
458 Kozlowski R. 1968. Nouvelles observations sur les conulaires. Acta Palaeontogica Polonica 459 13:497-531.

460 Kröger B., Penny A, Shen Y, Munnecke A. 2019. Algae, calcitarchs and the Late Ordovician

461 Baltic limestone facies of the Baltic Basin. Facies 66:1. DOI: 10.1007/s10347-019-0585-0

462 Lindström G. 1884. The Silurian Gastropda and Pteropoda of Gotland. Kongliga Svenska

463 Vetenskaps-Akademiens Handlingar 19:1-246.

464 Männil R. 1966. Istoria razvitiya Baltiyskogo bassena v ordovike. Tallinn: Valgus.

465 Meidla T, Ainsaar L, Hints L. 2014. The Ordovician System. In: Bauert H, Hints O, Meidla T,

466 Männik P, eds, Estonia. 4th Annual Meeting of IGCP 591, Estonia, 10-19 June 2014. Abstracts

467 and Field Guide. Tartu: Institute of Ecology and Earth Sciences, University of Tartu, 116-122.

468 Moore RC, Harrington HJ. 1956. Conulata. In: Moore, RC, ed. Treatise on Invertebrate

469 Paleontology. Part F, Coelenterata. Lawrence, KS: Geological Society of America, Boulder,

470 CO, and University of Kansas Press, F56-F66.

471 Moraes Leme J de., Guimarães Simoes C, Marques AC, Van Iten H. 2008. Cladistic analysis of

472 the suborder Conulariina Miller and Gurley, 1896 (Cnidaria, Scyphozoa; Vendian-Triassic).

473 Palaeontology 51:649-662.

474 Nestor H, Einasto R. 1997. Ordovician and Silurian carbonate sedimentation basin. In: Raukas

475 A, Teedumäe A, eds. Geology and mineral resources of Estonia. Tallinn: Estonian Academy

476 Publishers, 192-204.

477 Nõlvak J, Hints O, Männik P. 2006. Ordovician timescale in Estonia: recent developments.

478 Proceedings of the Estonian Academy of Sciences, Geology 55:95-108.

479 Oraspõld A, Kala E. 1980. Lithology of the Vormsi Stage in Estonia. Tartu Riikliku Ülikooli

480 Toimetised 527:51-74.

481 Podhalańska T, Nõlvak J. 1995. Endolithic trace-fossil assemblage in Lower Ordovician

482 limestones from northern Estonia. GFF 117:225-231 DOI: 10.1080/11035899509546220.

483 Raukas A, Teedumäe A. 1997. Geology and mineral resources of Estonia. Tallinn: Estonian

484 Academy Publishers.

485 Robson, SA, Young GA. 2013. Late Ordovician Conulariids from Manitoba, Canada. Journal of

486 Paleontology 87:775-785 DOI: 10.1666/12-0370.

487 Rõõmusoks A. 1966. Stratigrafiâ viruskoj i har'ûskoj serij (Ordovik) Severnoj Èstonii. D. Phil

488 Thesis, Tartu University.

489 Schmidt F. 1858. Untersuchungen über die Silurische Formation von Ehstland, Nord-Livland

490 und Ösel. Archiv für die Naturkunde Liv-, Ehst- und Kurlands 1. Serie (Mineralogische

491 Wissenschaften, nebst Chemie, Physik und Erdbeschreibung) 2:1-248.

492 Schmidt F. 1874. Miscellanea Siluria. Über einige neue und wenig bekannte Baltisch-Silurische

493 Petrefacten. Mémoires de L'Académie Impériale des Sciences de St.-Petérsbourg VIIe Série

494 21:1-46.

495 Seilacher A, MacClintock C. 2005. Crinoid Anchoring Strategies for Soft-Bottom Dwelling.

496 Palaios 20:224-240.

497 Seilacher A. 1984. Constructional morphology of bivalves: evolutionary pathways in primary

498 versus secondary soft-bottom dwellers. Palaeontology 27:207-237.

499 Sendino C, Broda K., Zatoń M. 2017 First record of true conulariids from the Upper Devonian of

500 Poland. Proceedings of the Geologists' Association 128:401-406 DOI:

$501 \quad$ 10.1016/j.pgeola.2017.03.004.

502 Sinclair GW. 1952. A classification of the Conularida. Fieldiana Geology 10:135-145. 
503 Steele-Petrovich HM. 2009 The biological reconstruction of Tetradium Dana, 1846. Lethaia 42: 504 297-311 DOI: 10.1111/j.1502-3931.2008.00146.x.

505 Størmer L 1931. Boring organisms in trilobite shells. Norsk Geologisk Tidsskrift 12:533-539.

506 Toom U, Vinn O, Hints O. 2019. Ordovician and Silurian ichnofossils from carbonate facies in

507 Estonia: a collection-based review. Palaeoworld 28(1-2):123-144.

508 Van Iten H. 1991. Anatomy, patterns of occurrence, and nature of the conulariid schott.

509 Palaeontology 34:939-954.

510 Van Iten H. 1992. Morphology and phylogenetic significance of the corners and midlines of the 511 conulariid test. Palaeontology 35:335-358.

512 Van Iten H, Moraes Leme, J de, Simões, MG., Cournoyer M. 2019. Clonal colony in the Early 513 Devonian cnidarian Sphenothallus from Brazil. Acta Palaeontologica Polonica 64(2): 409-416. 514 Vinn O, Kirsimäe K. 2014. Alleged cnidarian Sphenothallus in the Late Ordovician of Baltica, 515 its mineral composition and microstructure. Acta Palaeontologica Polonica 60:1001-1008.

516 Vinn O, Mironenko AA. 2020. Discovery of plywood structure in Sphenothallus from Gurovo 517 Formation (Mississippian), central Russia. Annales Societatis Geologorum Poloniae 90:1-9.

518 Walcott CD. 1886. Studies on the Cambrian Faunas of North America. Bulletin of the United

519 States Geological Survey 30:1-369 


\section{Figure 1}

Occurrences of Palaenigma wrangeli (Schmidt, 1874) in north Estonia

(A) Map of Baltoscandia with national boundaries and capitals (black dots). (B) Map of Estonia with $P$. wrangeli occurrences discussed herein (yellow dots), and with outline of Late Ordovician facies belts (from Harris et al., 2004). (C) Middle - Late Ordovician Regional stages of Baltoscandia (stars mark occurrences of $P$. wrangeli. Hirn., Hirnantian. Map data: R Package "maps” Version 3.3.0 ( https://cran.r-project.org/web/packages/maps/maps.pdf ).
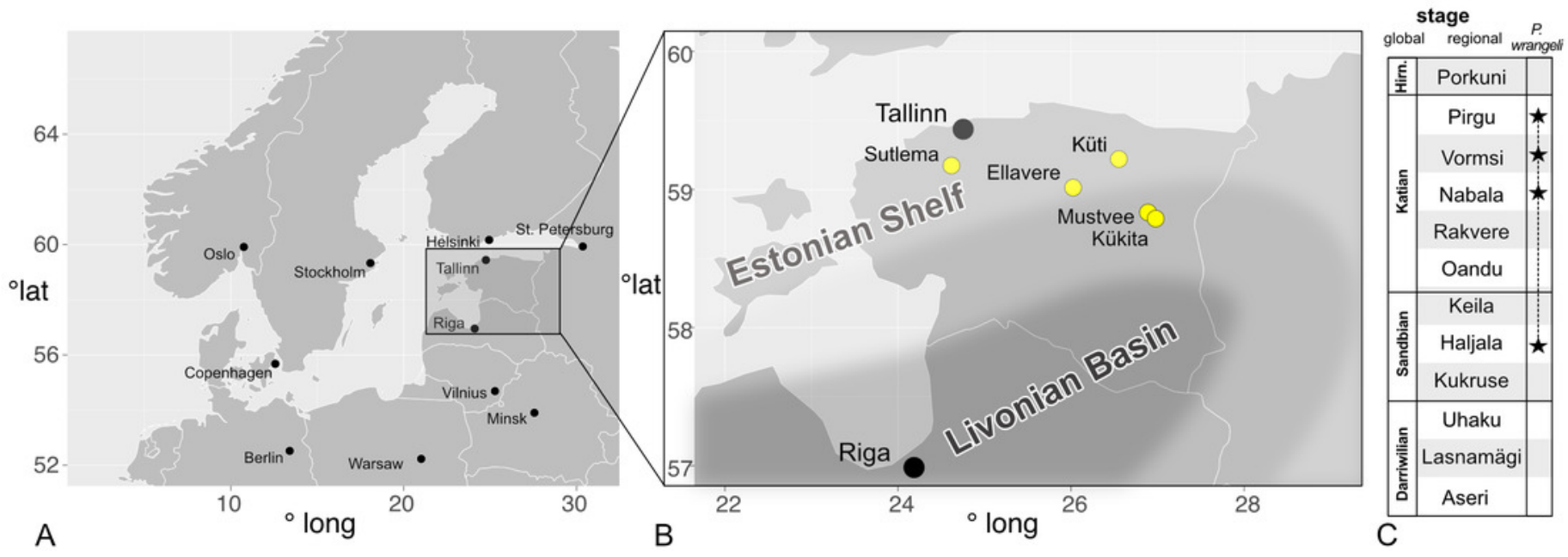
Figure 2

Schematic illustration of the morphological features of of Palaenigma wrangeli (Schmidt, 1874).

The descriptive terms are burrowed from the literature about conulariids (see text for details).

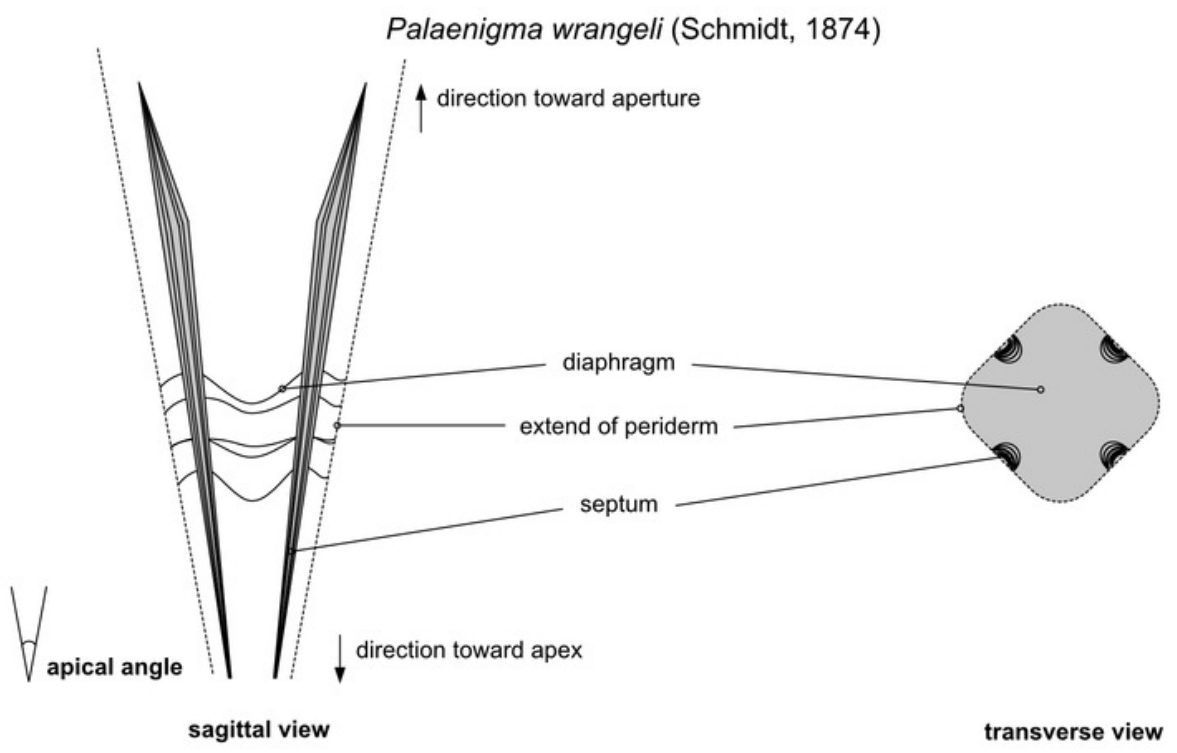




\section{Figure 3}

Specimens of Palaenigma wrangeli (Schmidt, 1874).

(A), (B). Specimen GIT 575-43 from Mäemetsa Quarry, Harju County, Estonia, Nabala Stage, arrow indicates traces of midline at outer wall, photos by G. Baranov, Tallinn. (C), (D).

Specimen specimen NRM-Mo 153045, from Küti quarry, near Viru-Jaagupi in northeastern

Estonia, Vormsi Stage. (E). Specimen GIT 655-2, from Ellavere drillcore, Järva County, northeast Estonia, Vormsi? Stage. (F), (G). Specimen GIT 812-34, from Sutlema quarry, west of Sutlema village, Rapla County, Estonia, Nabala Stage, photos by G. Baranov, Tallinn.
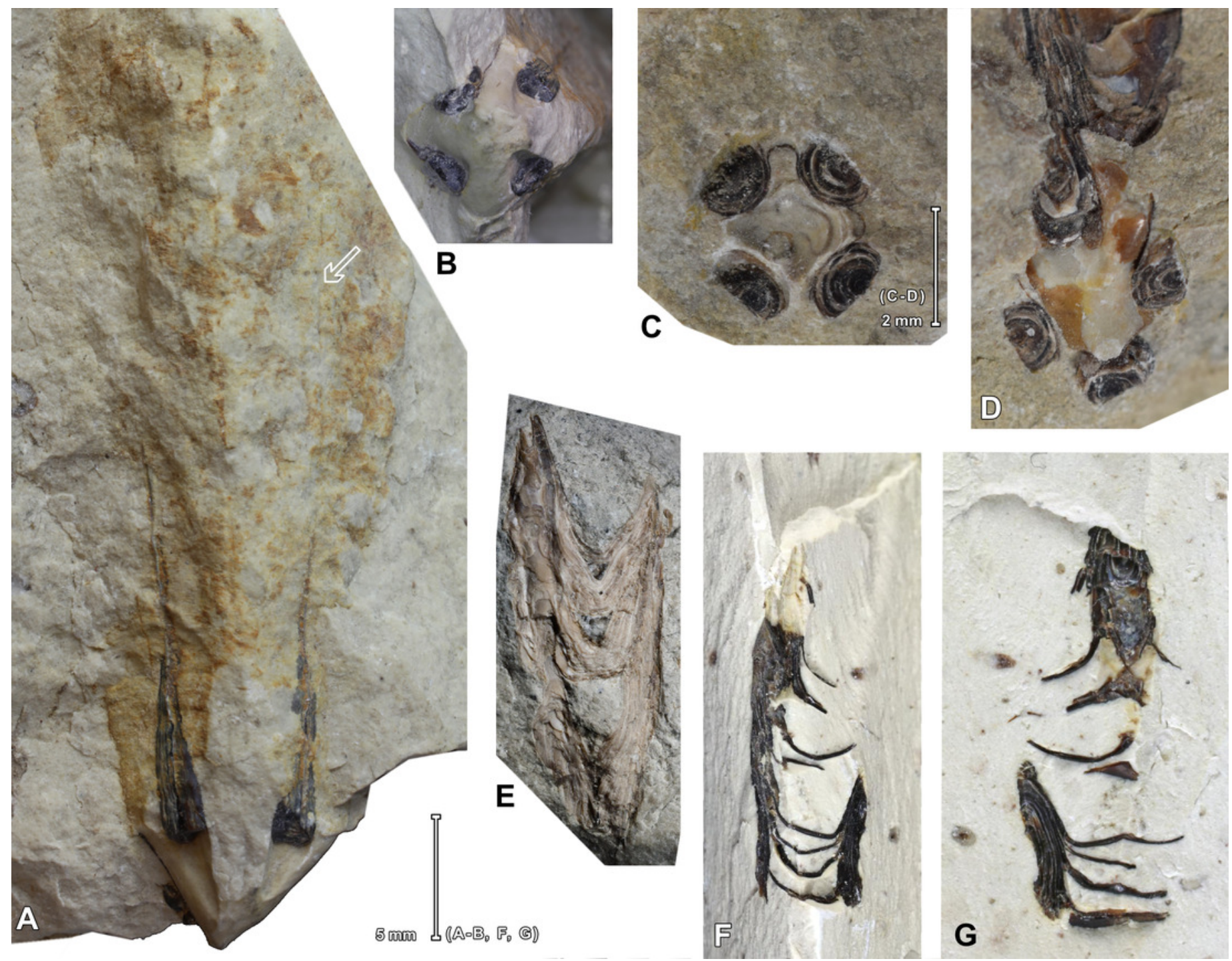


\section{Figure 4}

Micro-CT images of Palaenigma wrangeli (Schmidt, 1874), specimen GIT 812-34, from Sutlema quarry, west of Sutlema village, Rapla County, Estonia, Nabala Stage.

(A) Lateral view. (B) Lateral view $90^{\circ}$ rotated along the growth axis relative to A. (C) Lateral view parallel to two pillars. Scale applies to all figures. Tried-and-true 3D XYZ cross with Xaxis (red), y-axis blue, z-axis green.
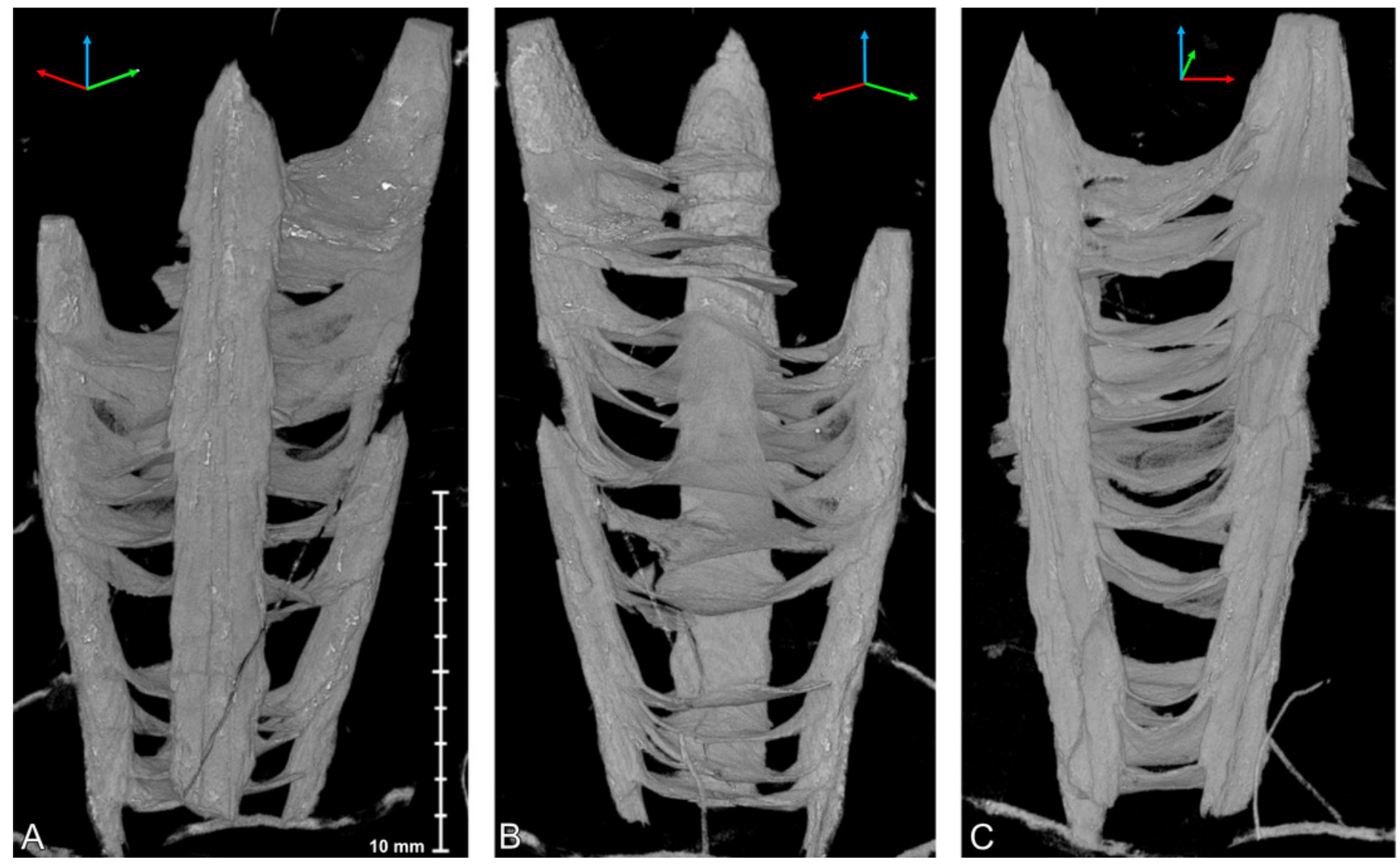


\section{Figure 5}

Micro-CT images of Palaenigma wrangeli (Schmidt, 1874).

(A), (B). Specimen GIT 812-34, from Sutlema quarry, west of Sutlema village, Rapla County, Estonia, Nabala Stage. A. Sagittal cut. B. Transverse cut. (C), (D). Specimen NRM-Mo 153045, from Küti quarry, near Viru-Jaagupi in northeastern Estonia, Vormsi Stage. C. Transverse cut.

D. Sagittal cut. Note the irregular spacing of the diaphragms and the continuation of the diaphragm - pillar layers in A and D, and the open half-circle cross section shape of the pillars in C and D. Scale applies to all figures. 

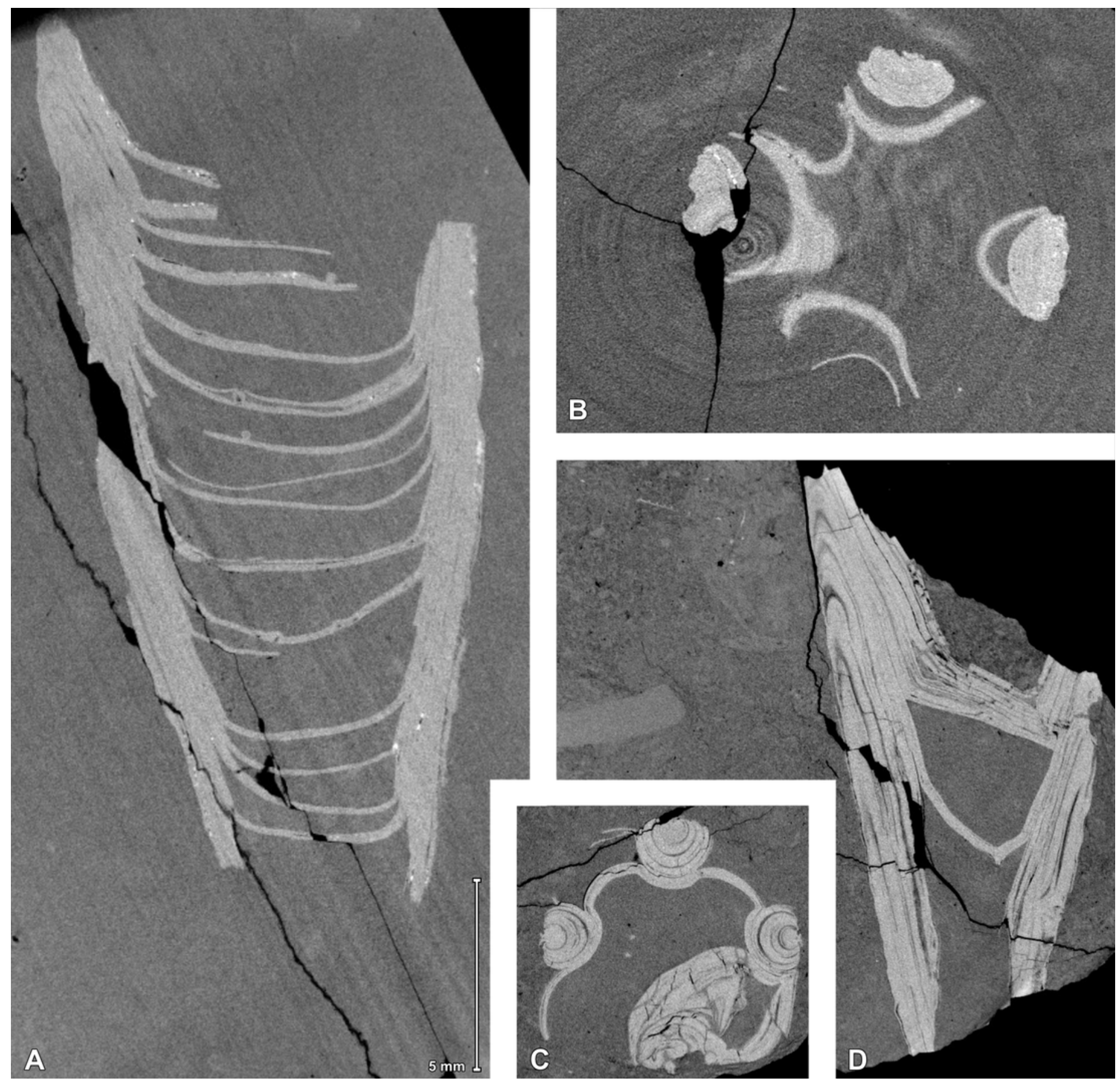


\section{Figure 6}

Micro-CT images of Palaenigma wrangeli (Schmidt, 1874), specimen NRM-Mo 153045, from Küti quarry, near Viru-Jaagupi in northeastern Estonia, Vormsi Stage.

(A) Lateral view, scale applies to A, and B. (B) Lateral view $180^{\circ}$ rotated along the growth axis relative to A. (C) Adapical view, scale applies to C, D. (D) Adoral view. Tried-and-true 3D $X Y Z$ cross with $x$-axis (red), $y$-axis blue, $z$-axis green.
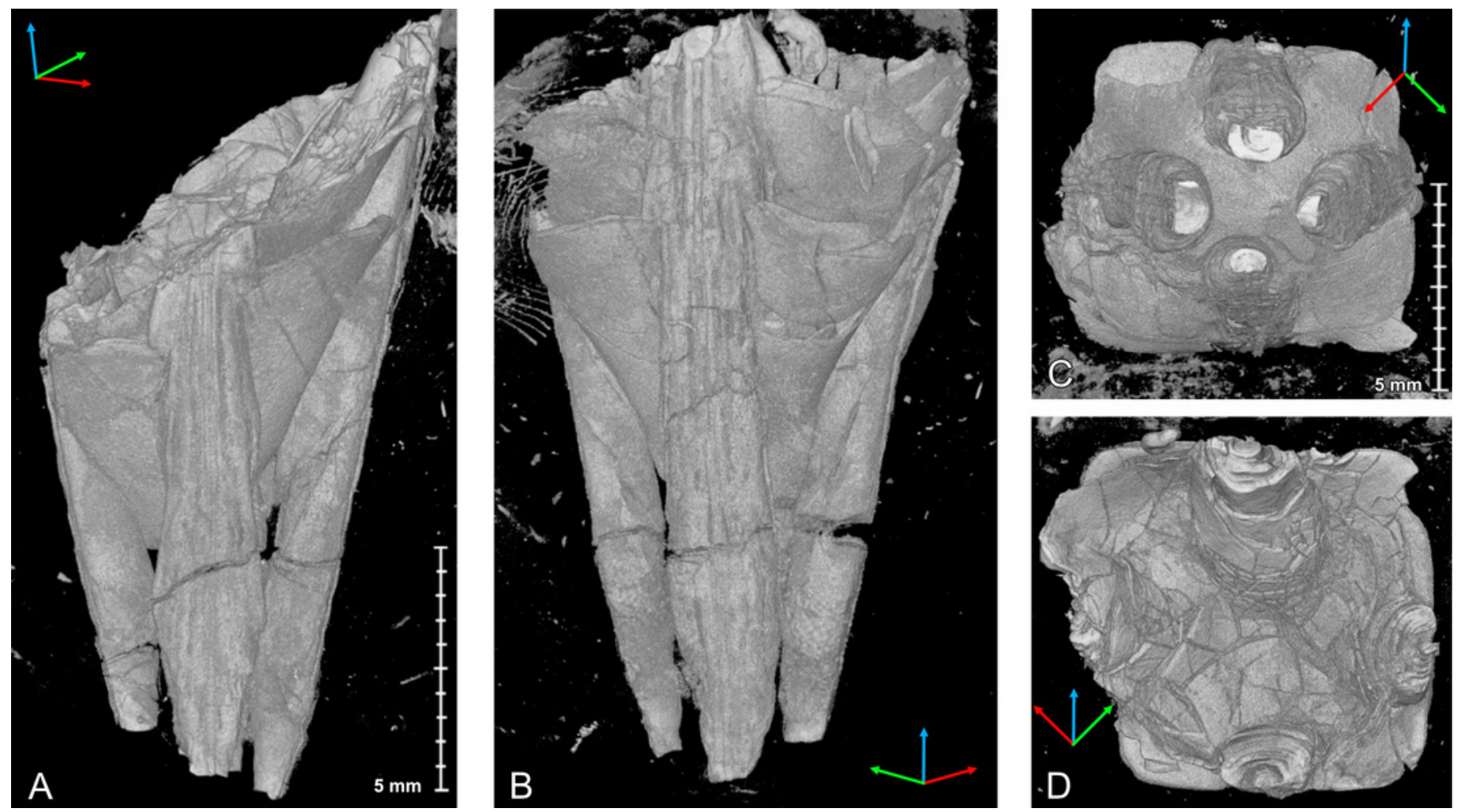


\section{Figure 7}

Micro-CT image of Palaenigma wrangeli (Schmidt, 1874), specimen GIT 655-3, from Mustvee 2322 drillcore, west of Mustvee, north-east Estonia, Pirgu Stage.

. (A) Lateral view. (B) Lateral view $90^{\circ}$ rotated along the growth axis relative to A. (C) Lateral view $180^{\circ}$ rotated along the growth axis relative to $A$. Scale applies to all figures. Tried-andtrue 3D XYZ cross with $x$-axis (red), y-axis blue, z-axis green.
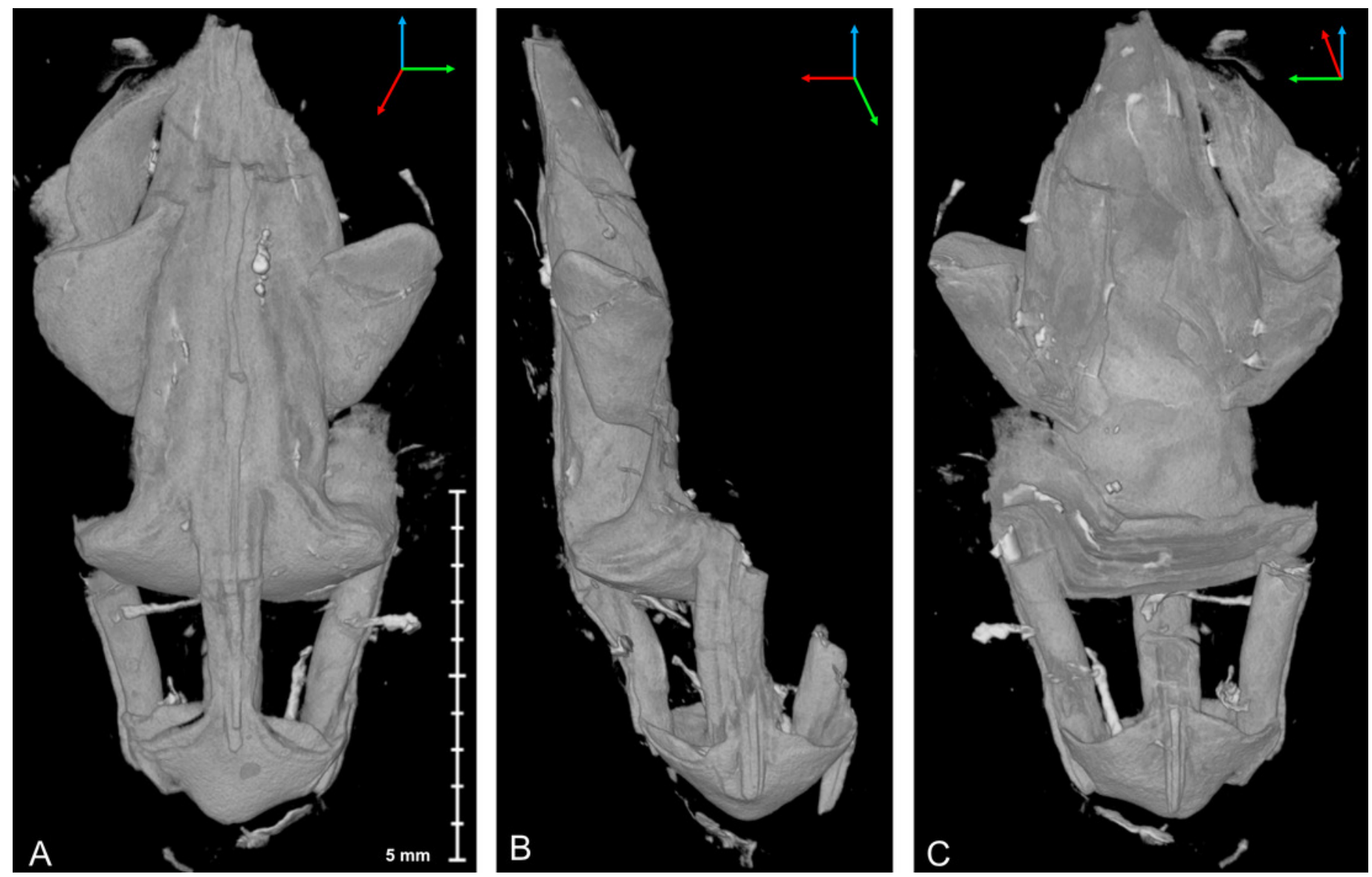


\section{Figure 8}

Micro-CT image of Palaenigma wrangeli (Schmidt, 1874) and conulariid fragments.

(A) Lateral view of specimen GIT 655-3 with unidentified skeletal debris in surrounding sediment matrix and fragment of conulariid (upper right). (B) Lateral view of specimen NRMMo 153045 with unidentified skeletal debris in surrounding sediment matrix and fragment of conulariid (upper right). (C) Lateral view of conulariid GIT 812-35-1, from Sutlema quarry, Nabala stage, note also the disc-like shadow of a crinoid ossicle in the sediment matrix. Tried-and-true 3D XYZ cross with $x$-axis (red), y-axis blue, z-axis green.
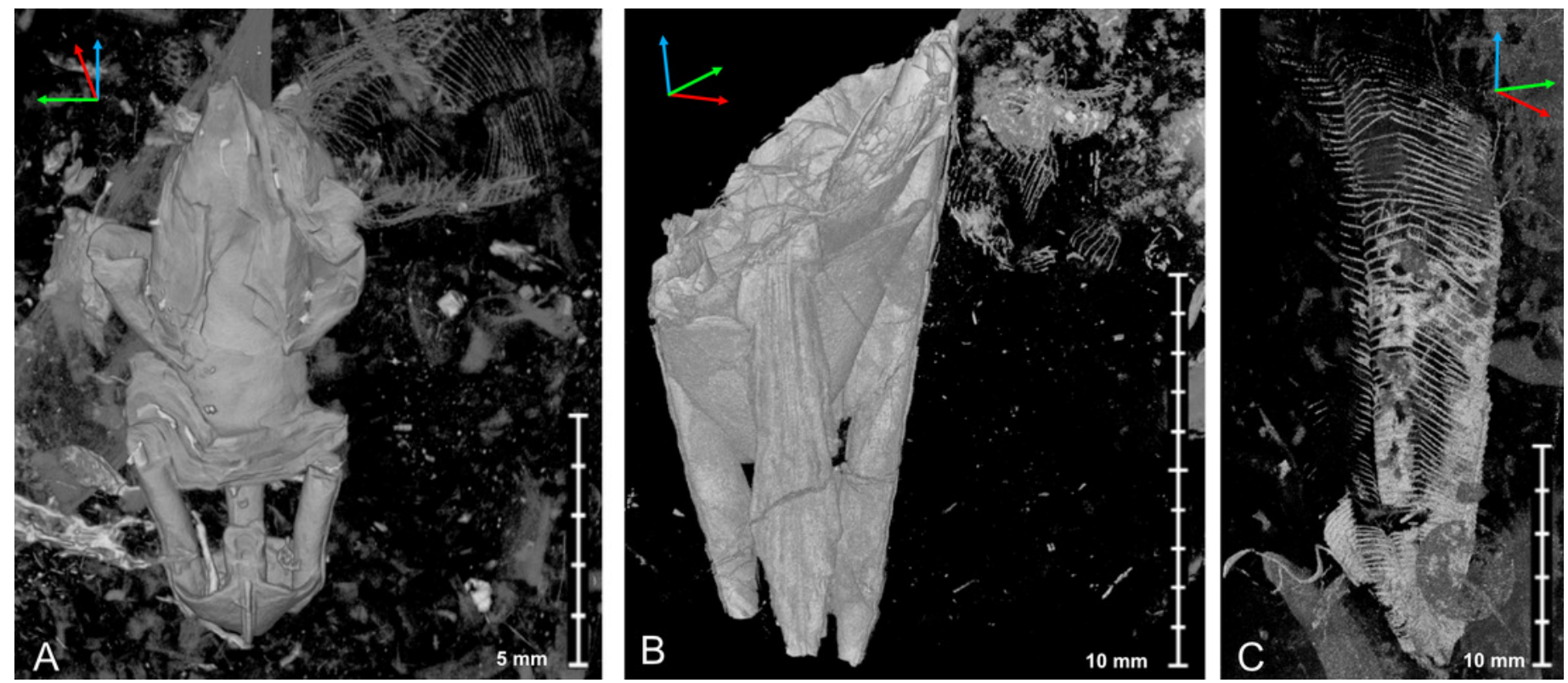


\section{Figure 9}

Scanning electron images of Palaenigma wrangeli (Schmidt, 1874).

(A), (D). Specimen GIT 655-1, from Kükita 24 drillcore, Mustvee Parish, north-east Estonia, Vormsi Stage, showing fragment of a transversally ornamented periderm? near external surface of a pillar. (B), (C), (E)-(I). Specimen GIT 655-2, from Ellavere drillcore, Järva County, north-east Estonia, Vormsi? Stage. B, E, F. Area with distinctive papillate surface and with wrinkles (arrow in F). G-I. Details showing lamellate conch cross section with empty or filamentous interspaces (arrow in G). Note also the chimney like structures (arrow in $\mathrm{H}$ ). 

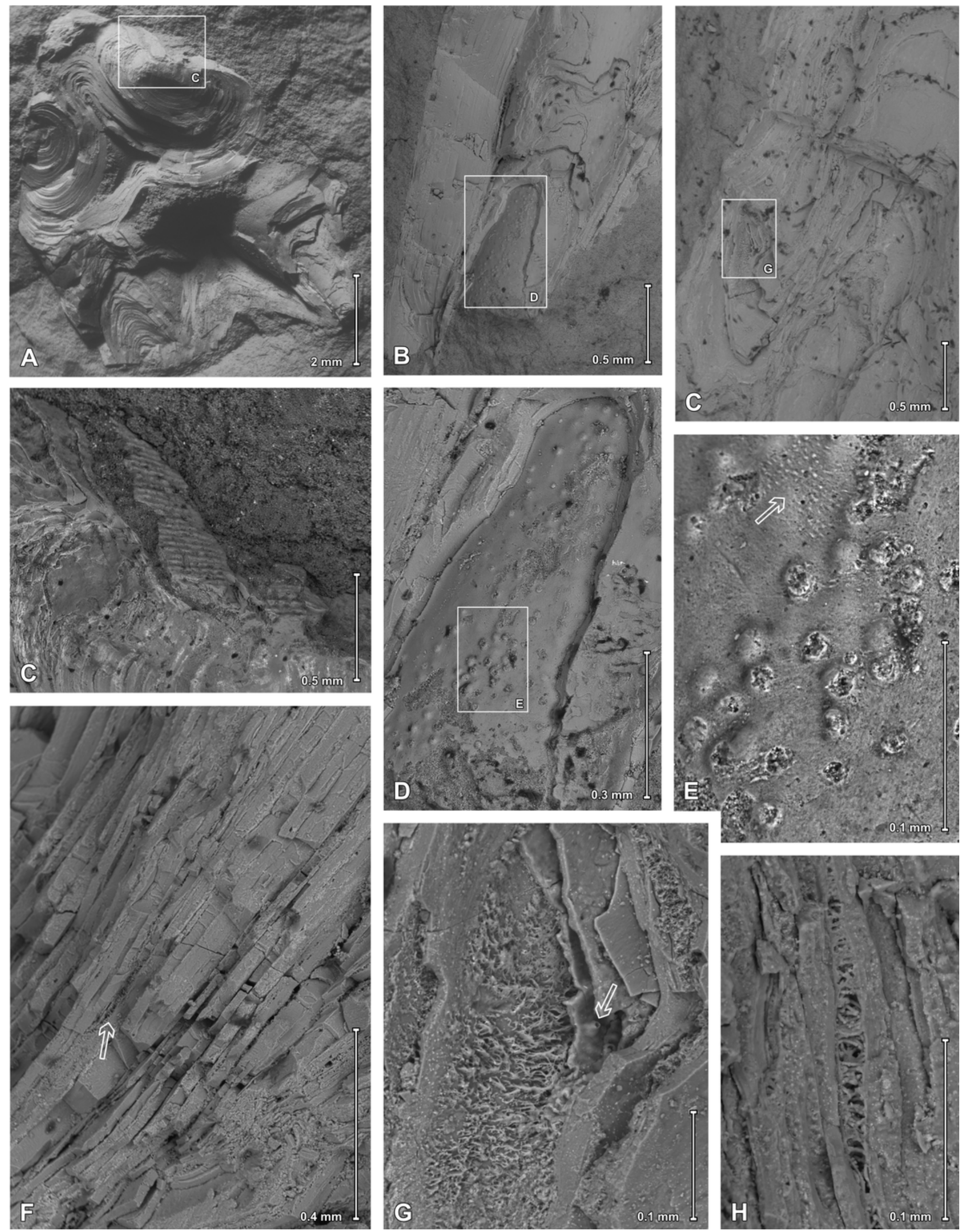


\section{Figure 10}

Abundance ( $=$ frequency of occurrences) of conulariids in Estonian Ordovician strata and stratigraphic occurrence of Palaenigma wrangeli (Schmidt, 1874).

Hirn., Hirnantian; n, number. Data: downloaded from SARV at 08.04.2021(see also Methods section and Data S5). 
stage

global regional

\begin{tabular}{|c|c|}
\hline 寅 & Porkuni \\
\hline \multirow{5}{*}{ 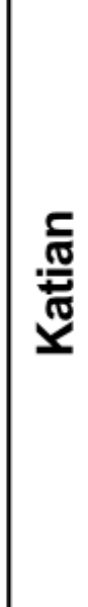 } & Pirgu \\
\hline & Vormsi \\
\hline & Nabala \\
\hline & Rakvere \\
\hline & Oandu \\
\hline \multirow{3}{*}{ 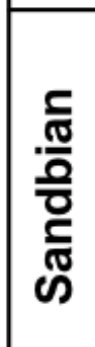 } & Keila \\
\hline & Haljala \\
\hline & Kukruse \\
\hline \multirow{4}{*}{ 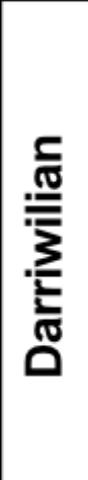 } & Uhaku \\
\hline & Lasnamägi \\
\hline & Aseri \\
\hline & Kunda \\
\hline
\end{tabular}
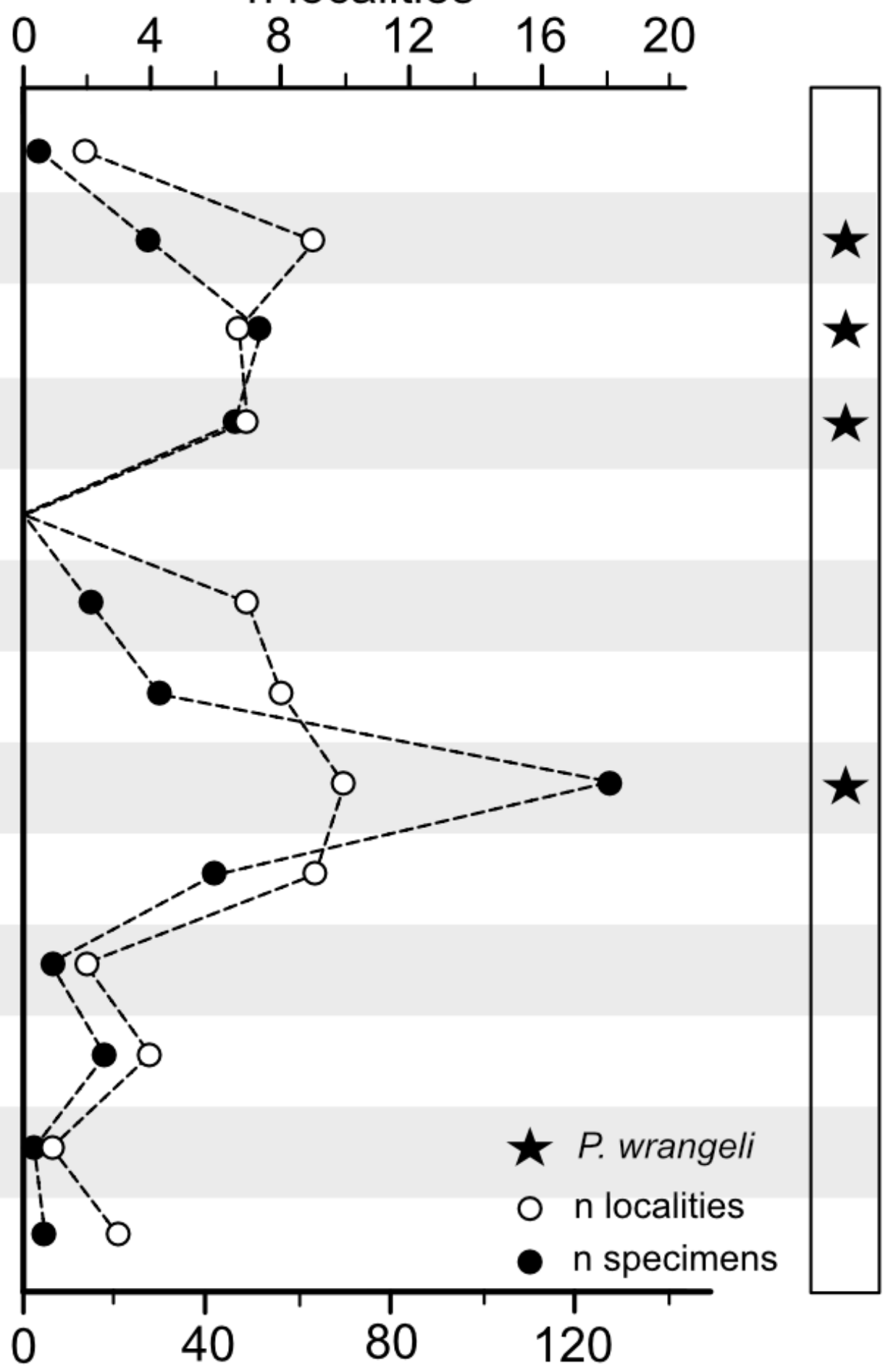

n specimen 